\title{
An Analysis on COVID-19 Disinformation Triangle in Indonesia
}

\author{
Senja Yustitia ${ }^{1, \text { a) }}$ Panji Dwi Ashrianto ${ }^{2)}$ \\ ${ }^{1}$ Department of Communication Science, UPN “Veteran" Yogyakarta \\ a) senja.yustitia@upnyk.ac.id \\ ${ }^{2}$ Department of Communication Science, UPN “Veteran” Yogyakarta
}

DOI: https://doi.org/10.18196/jkm.122040

\section{Article Info}

Article history:

Received 3 Oct 2020

Revised 13 Nov 2020

Accepted 24 Nov 2020

\section{ABSTRACT}

Misinformation and disinformation are widespread in society, as well as during the outbreak of COVID-19. Much of this information is partly accurate, but the others are not, making it difficult for people to find reliable sources and guides. This study aims to see the tendency of misinformation and disinformation related to COVID-19, which has been fact-checked by Mafindo in January - July 2020 period using quantitative content analysis. The misinformation and disinformation criteria refer to the seven UNESCO types. They were analyzed using the disinformation triangle model by Victoria L. Rubin. The results showed that the highest intensity of COVID-19 misinformation and disinformation was in March, April, and May. Misinformation and disinformation are mostly disseminated through the platforms like Facebook, Twitter, and WhatsApp. The types of content that are most widely shared are misleading content, fabricated content, and false context. Besides, personal opinions are also the source of the most common COVID-19 misinformation during January-July 2020.

Keywords: COVID-19; Disinformation; Indonesia; Misinformation

\section{ABSTRAK}

Misinformasi dan disinformasi tersebar luas di masyarakat, juga terjadi saat merebaknya COVID-19. Banyaknya informasi ini sebagian akurat, dan selebihnya tidak, menyulitkan orang untuk menemukan sumber dan panduan yang dapat dipercaya. Penelitian ini bertujuan melihat kecenderungan misinformasi dan disinformasi terkait COVID-19 yang telah dicek fakta oleh Mafindo pada periode Januari - Juli 2020 menggunakan analisis konten kuantitatif. Fokus penelitian ini adalah mengidentifikasi media penyebaran disinformasi, jenis, dan sumber misinformasi di Indonesia. Kriteria misinformasi dan disinformasi mengacu pada tujuh tipe milik UNESCO dan dianalisis menggunakan model segitiga disinformasi oleh Victoria L. Rubin. Hasil penelitian menunjukkan intensitas misinformasi dan disinformasi COVID-19 tertinggi ada pada bulan Maret, April dan Mei. Misinformasi dan disinformasi paling banyak disebarkan melalui platform Facebook, Twitter dan WhatsApp. Jenis konten yang paling banyak disebarkan adalah konten yang menyesatkan, konten palsu serta konten yang salah. Selain itu, opini personal juga menjadi sumber misinformasi COVID-19 paling banyak sepanjang bulan Januari-Juli tahun 2020.

Kata Kunci: COVID-19; Disinformasi; Indonesia; Misinformasi 


\section{INTRODUCTION}

Misinformation and disinformation are false and inaccurate information. The main difference between both of them is in the aspect of intention whether the information is intended to deceive. Disinformation is usually used to refer to intentional case, while misinformation is not intentional (Wu, Morstatter, Carley, \& Liu, 2019). Beside the two terms, there are also the other ones known as hoax and fake news. Hoax is a popular term used to call fake information (Nadzir, Seftiani, \& Permana, 2019), while fake news is intentionally widespread misinformation in the form of news (Wu et al., 2019).

In Indonesia, misinformation and disinformation started to be known by society since the regional election event in DKI (Special Capital Region) in 2012, and they got massively used in the regional election of DKI in 2017. This phenomenon continued into the general election and finally it becomes something that often happens in events that attract the intention of society. The theme also broadens, not only related to politics but also connected to other problems such as health and education (data). The research carried out by Tirto with (International Center for Journalist (ICFJ) fellow, Astudestra Ajeng Rastri, in February 2019 showed that health issue got the highest position of 18 claims and hoax pictures given to the respondents (Ariani, 2019). After health issue, there are also issues of nationalism, economy, religions and politics.

Hoax does not only make people worried because of the false information (Hesthi Rahayu \& Utari, 2018), but also, in some incidents, it caused the loss of some people's lives. For example, there was an Indian beaten to death by 2,000 people because of being accused as child kidnapper through WhatsApp text spreading (Salsabila, 2018). Related to health issue, ScienceAlert reported news that an international group of researchers on communicable diseases analyzed the misinformation related to COVID-19 that spread in the internet (Wibawa, 2020). The result was that there were 2,300 reports on hoax and conspiracy theory in 25 languages in 87 countries. The misinformation made the number of dead caused by corona virus increase. For example, in South Korea, it caused 50 congregations got infected by COVID-19 because they used the same bottle to spray salt water into the mouth of the congregations believing that it would help to prevent the spread of corona virus (Oliveira, 2020).

According to the data of Masyarakat Anti Fitnah Indonesia (Mafindo) or Anti-Defamation Society of Indonesia by the end of July, the case number of misinformation and disinformation whose facts have been checked from January until September was 540 (Sasmito, 2020). Until March 2020, Polda Metro Jaya or Regional Police of Jakarta has handled 43 hoax cases related to the corona virus plague. Meanwhile, according to the file of Kominfo (Communication and Informatics) Department there were at least 196 hoax and disinformation about corona virus in Indonesia (Nafi'an, 2020; Putri, 2020). It shows that the misinformation spreading in society is quite massive.

The restlessness on the condition, especially if globally related to COVID-19 pandemic, brings a term out called infodemic (Brennen, Simon, Howard, \& Nielsen, 2020; Cinelli et al., 2020; Zarocostas, 2020). Infodemic is information-overloaded whose some of its part are accurate and the rest is not, so people find it difficult to get source that can be trusted and reliable guide (WHO, 2020). The restlessness is even responded by WHO (World Health Organization) by tracking rumors, myths, and misleading health information spreading in social media.

The significant effect of misinformation spread is that people find it difficult to get the right information. Misinformation also causes commotion amid society because of the emergence of reactions on the news whose truth is questioned. In a crisis situation, the truth of information becomes very significant because it is related to the steps of solution and control of crisis. That is why, the emergence of misinformation and disinformation makes society and government focus not only on problem solution, but also on the effect of misinformation emergence.

This research will observe the tendency of misinformation and disinformation related to COVId-19 that spread in Indonesia during January - July 2020 period. It also focuses on identifying the spread media, and type and source of misinformation and disinformation in Indonesia. Because there is much information about COVID-19 that spreads, the researcher will only focus on the cases stated as misinformation and disinformation by Mafindo, the fact checker institution.

The concept of misinformation and disinformation used in this research refers to the 7 types proposed by UNESCO and adopted by First Draft. They are satire/ parody, misleading content, fabricated content, imposter content, false connection, false context and manipulated content (Posetti et al., 2018; Wardle, 2017). Meanwhile, generally, disinformation according to First Draft is content intentionally made to be fake and planned to cause harm (Wardle, 2019). Its difference from 
misinformation is when disinformation is often spread, then it becomes misinformation. In misinformation, the perpetrator is not aware that the information is wrong or misleading (Karlova \& Fisher, 2013; Posetti et al., 2018; Wardle, 2019).

This research used The Disinformation Triangle model (Figure 1) by Victoria L. Rubin to analyze the research result. Disinformation Triangle Model describes the spread of misinformation and disinformation like virus infection. The triangle model elaborates 3 cause factors in digital news context. First; virulent pathogen is falsifications, clickbait, satirical fakes and the other news content that is deceiving or misleading. The second factor is susceptible host. It refers to the condition of news readers and information seekers who have limited time to do verification. Rubin also highlights the existence of information- overloaded factor in this aspect. The third factor is conductive environment that refers to the condition of polluted digital environment such as bad platform including the freedom of users as a part of user- generated content that supports the spread of various fake content (Victoria L. Rubin, 2019; Victorial L. Rubin, 2018).

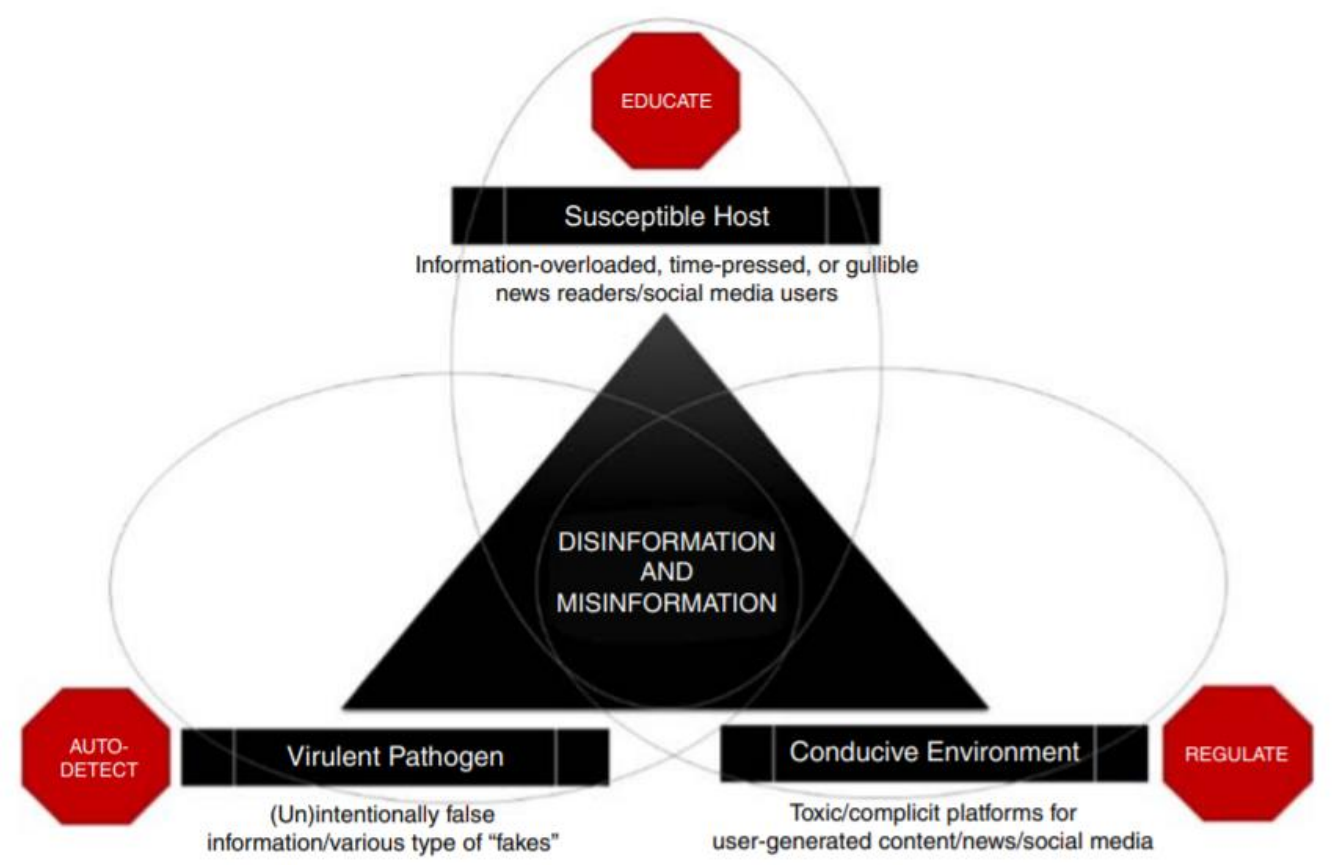

Figure 1. The Disinformation Triangle Model

(Source: Victoria L. Rubin, 2019)

Automation is an automatic identification endeavour that can detect fake news. Rubin stated that detection system of fake news can find various falsity with accuracy achieving 76 percent or it is equal to the ability of human in recognizing fake news content or information (Victoria L. Rubin, 2019). This kind of detection, according to Rubin, is a supporting technology that can be developed and becomes a part of solution even though in general it does not replace the role of human.

The next is literacy or education strategy that can be used as a part of solution on the recent condition, for example information which is overloaded and accessible with communication technology aid. Based on this model, information literacy endeavour is an urgent need especially for vulnerable groups of society like young adults, parents, and people with low education level or computer literacy (Victoria L. Rubin, 2019).

Then, there should be a regulation that becomes the focus of legislature. They are supposed to be more proactive and hand in hand with global society to eradicate disinformation and misinformation just like pathogen. Generally, the model can be explained in 3 points. Firstly, automation is used to help human in ceasing and controlling disinformation. Secondly, integrated endeavour in education is used "to inject" society and to create citizens who are more critical towards information. Thirdly, a regulation is implemented so that social media is more conducive. Thus, it elucidates polluted news. Therefore, it prevents social media platform from pursuing short term profit only and sacrificing human rights, democracy, and public safety (Victoria L. Rubin, 2019). 
Studies on the aspects of message and information about COVID-19 has been carried out by researchers from all over the world, including Indonesia. For example, Riyanti Djalante et al. analyzed the gap and opportunity in responding COVID-19 emergency state, including giving some recommendations for rapid, comprehensive and systematic approach, both in short and in long terms (Djalante et al., 2020). The research result by Zapan et al. also gives recommendation that authorities have to make sure that society is guaranteed with safety from getting wrong information that leads to exploitation (Barua, Barua, Aktar, Kabir, \& Li, 2020). The relationship between the characteristics of society including demographic factor and how they respond to COVID-19 was studied by Jesica Moudy et al. and Narila Mutia Nasir et al. (Moudy \& Syakurah, 2020; Nasir, Baequni, \& Nurmansyah, 2020). Radityo Widiatmojo highlighted COVID-19 from visual literacy aspect as a part of hoax prevention (Widiatmojo, 2020). Meanwhile, Rochani Nani Rahayu and Sensusiyati analyzed hoax news of COVID-19 in social media by searching the keywords of hoax and corona in news media (Rahayu \& Sensusiyati, 2020). The risk of social media misinformation amplification was also discussed by researchers from Vietnam (Nguyen \& Nguyen, 2020).

The novelty offered by the researchers is that this research uses more detail concepts of misinformation and disinformation referring to the criteria that the researchers have adopted from UNESCO and First Draft. In addition, the researchers focus on the media of the spread in social media including WhatsApp. Thus, this research obtained the trend description of misinformation and disinformation spread of COVID-19 in Indonesia in the given period. The use of The Disinformation Triangle model in analyzing the research result has also made this research not only perceive the tendency of misinformation and disinformation, but also relate it with the other aspects.

\section{METHODS}

The method used in this research was quantitative content analysis (Eriyanto, 2011; White \& Marsh, 2006). The researchers carried out the coding on 449 cases stated as misinformation and disinformation by Mafindo in January- July 2020 period. The research stage was started by designing analysis unit and category, and then it was continued by carrying out the coding on the cases in the period. The coding was carried out by 3 coders. After the coding, the next is validity and reliability tests before the researchers conducted the frequency analysis. The analysis unit and category used in this content analysis focused on 3 things as follows;

Table 1. Analysis Unit and Category

(Source: The Researchers's Design, 2020)

\begin{tabular}{cll}
\hline No & \multicolumn{1}{c}{ Category } & \multicolumn{1}{c}{ Analysis Unit } \\
\hline 1 & The media of misinformation and & FB \\
& disinformation spread & Twitter \\
& & WhatsApp \\
& & Website \\
& & Youtube \\
\hline 2 & The types of misinformation and & Satire/ parody \\
& disinformation & Misleading content \\
& & Imposter content \\
& & Fabricated content \\
& & False connection \\
& & False context \\
\hline 3 & The source of misinformation and & Manipulated content \\
& disinformation written in the content & News website \\
& & Social media \\
& & Personal opinion \\
& & Public figure \\
& & Main stream mass media \\
\hline
\end{tabular}




\section{RESULT AND DISCUSSION}

Figure 2 shows the general description of misinformation and disinformation during January- July. The highest intensity of misinformation was in March. The first COVID-19 patient in Indonesia was detected by the end of February. The patient who was then called as patient number 1 was stated COVID-19 positive on March 2, 2020. This is the case that becomes the beginning of awareness of the society and government on the corona plague situation in Indonesia.

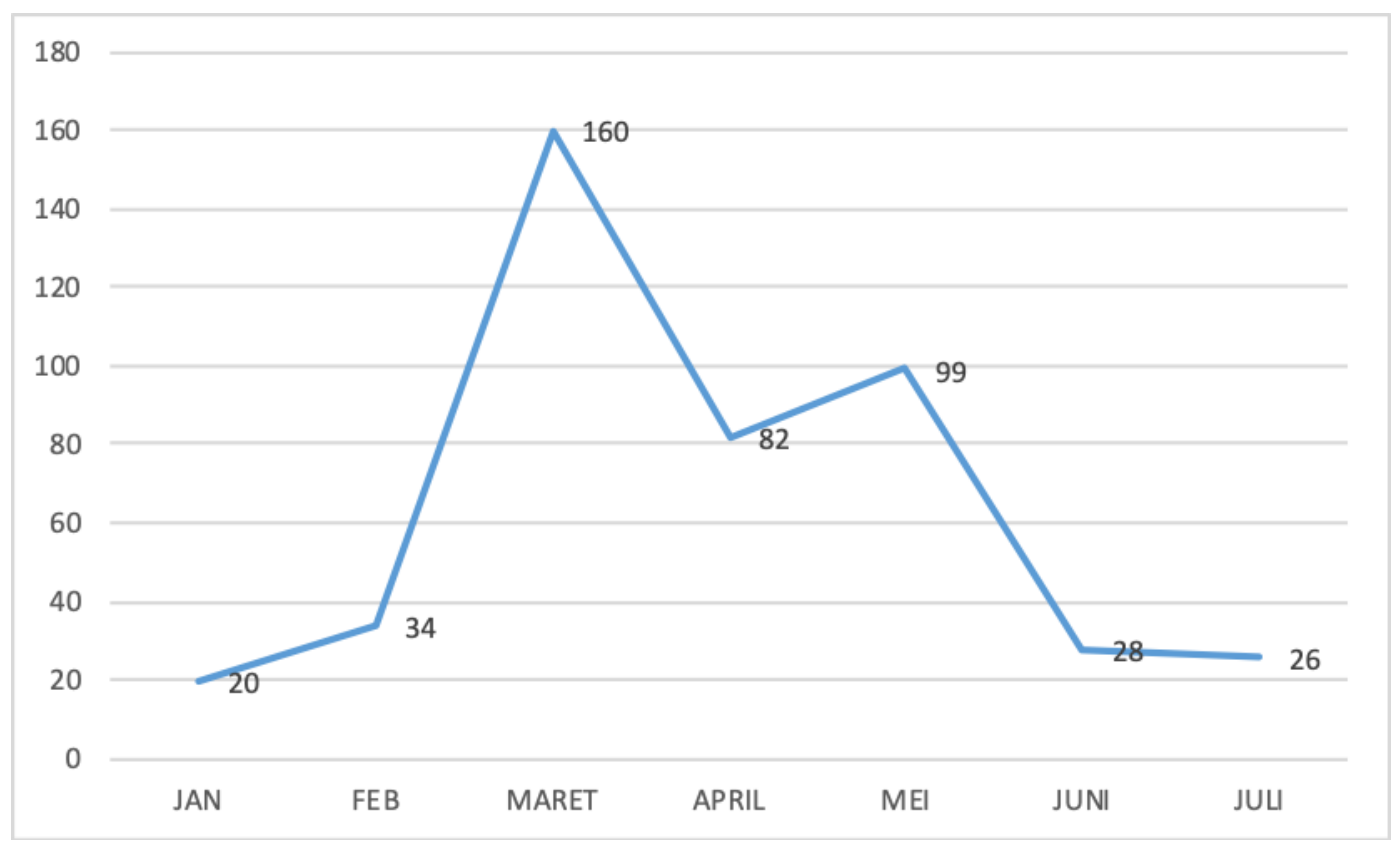

Figure 2. Number of Misinformation and Disinformation in January - July 2020 (Source: Primary Data, 2020)

Even though the society has known that the plague actually exists and spread in Wuhan China for the first time, the geographic distance that is quite far and Wuhan which is not very famous as a city, have made the information about the pandemic is not very convincing. However, the assurance that COVID-19 has come and infected Indonesian society (patient 1 and patient 2) generally makes the case has higher proximity. It is also related to misinformation and disinformation.

Meanwhile, the number of misinformation and disinformation in April and May was almost similar. It can be concluded that even though the level of misinformation and disinformation decreased from March to April, the fluctuation was not very different. The attention of the society on COVID-19 was still high in April because of some things. For example, DKI Jakarta in April 10, officially enforced PSBB (Pembatasan Sosial Berskala Besar or Large-Scale Social Restriction). In Indonesia, there were some cities that officially were given permission to enforce PSBB by midApril, namely Bodebek area in Jawa Barat such as Bogor City, Bogor Regency, Bekasi City, Bekasi Regency, and Depok City. In Bandung Raya area, there were Bandung City, Cimahi City, Bandung Regency, Bandung Barat, and Sumedang in April 22. Outside Jawa Island, there were Pekanbaru City in Riau, Makassar City in Sulawesi Selatan in April 24.

The commotion related to lockdown, micro lockdown, the other terms referring to the intention occurred in every area in Indonesia especially in the cities in Jawa Island. In Yogyakarta, by midApril, some villages closed the areas or known as local lockdown (Syambudi, 2020).

The important event that happened in May was Idul Fitri (Eid al- Fitr). The Idul Fitri celebration amid the pandemic changed the traditions that have been existing all these times. For example, they were the low intensity of homecoming, the Idul Fitri congregation prayers which were not held in the cities not allowed (red zone), and the decrease of visiting activities. 


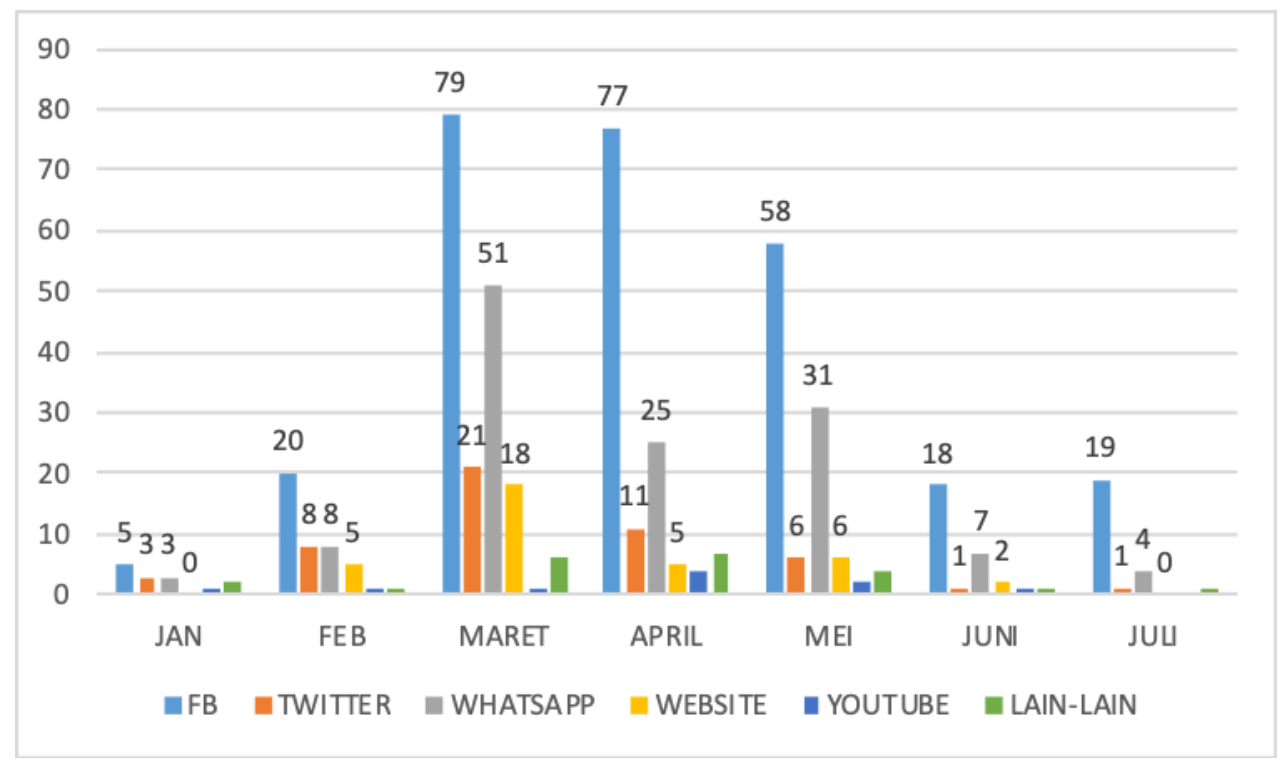

Figure 3. The Media of Misinformation and Disinformation Spread (Source: Primary Data, 2020)

From figure 3, it can be seen that Facebook always became the media of misinformation and disinformation spread with the highest percentage during January - July 2020. The active users of Facebook in Indonesia were 2.49 billion per April 2020, and it became the highest number in Indonesia (Databoks, 2020). Meanwhile, in the category of the social media often used in Indoesia, Facebook was in the third place after Youtube and WhatsApp (Dwi Hadya Jayani, 2020). In general, Facebook is also easier to operate and its users have freedom to upload many kinds of content form, such as text, picture, and video. The unlimited number of characters in Facebook, unlike Twitter only 140 words - makes the misformation and disinformation message can be more completely delivered through Facebook. The features that are easy to operate and the quite big number of users become the main factors of this finding.

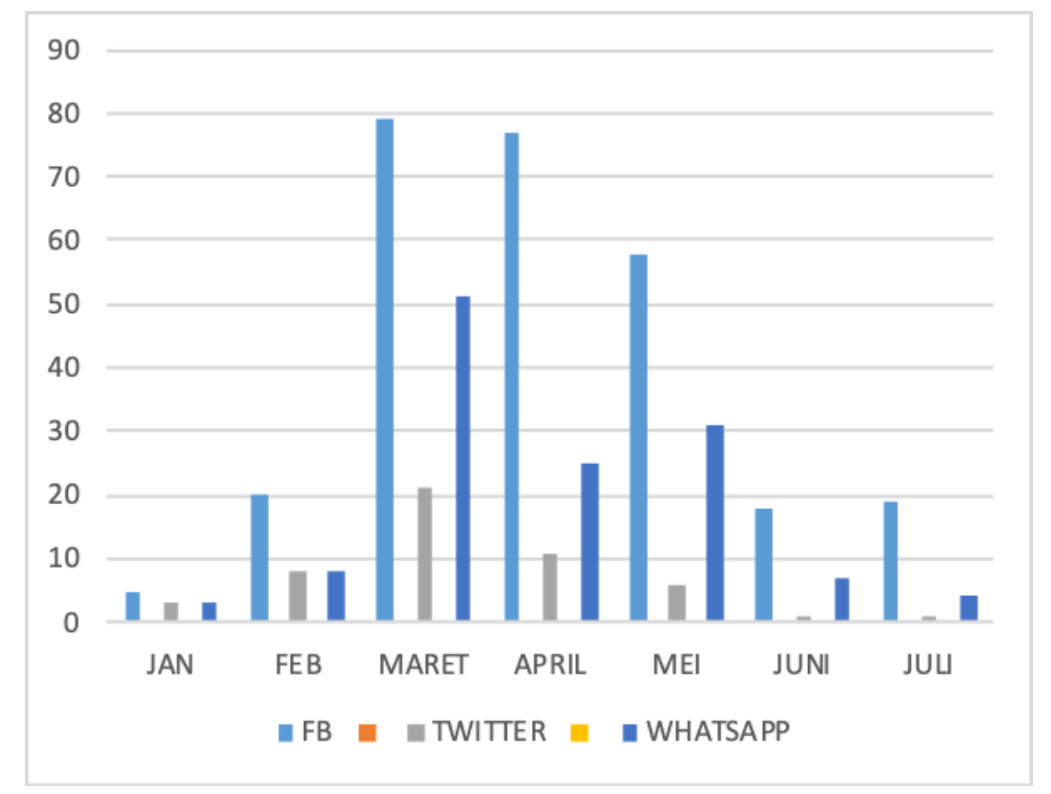

Figure 4. The Three Media with Most Misinformation and Disinformation Spread (Source: Primary Data, 2020) 
Beside Facebook, the other media also used to spread misinformation and disinformation are WhatsApp and Twitter. Both are media with text- based characteristic. Even though text based, they can still be used to create audio- visual content.

The active users of WhatsApp in Indonesia are 2 billion or in the third place after Facebook and Youtube (Databoks, 2020). WhatsApp has the advantage of being easily used in information distribution. The group making feature with 256 members at maximum makes WhatsApp become a media that is really easy to use to spread misinformation. Even though in January 2019 WhatsApp enforced new regulation, namely restricting the users to forward message for only 5 times at maximum to stop the rumor chain (Potkin, Damiana, \& Mano, 2019), the policy did not seem to give much effect.

The misinformation spread through WhatsApp is also almost without punishment. People can easily send false news without fearing of sanction. Even though in Indonesia the police can trace the WhatsApp number, the case rarely happens because the group usually consists of members in 1 circle of friendship or interest.

Twitter is also one of the most popular media in Indonesia. In the top 10 most widely used social media, Twitter is in the fifth place after Youtube, WhatsApp, Facebook, and Instagram (Dwi Handya Jayani, 2020). Through Twitter, beside text, the users can upload picture and video. Its users can also be anonymous because this media does not require them to give personal data. The use of bot and manipulation platform (Roth \& Pickles, 2020) make the opportunity of misinformation and disinformation spread widely open.

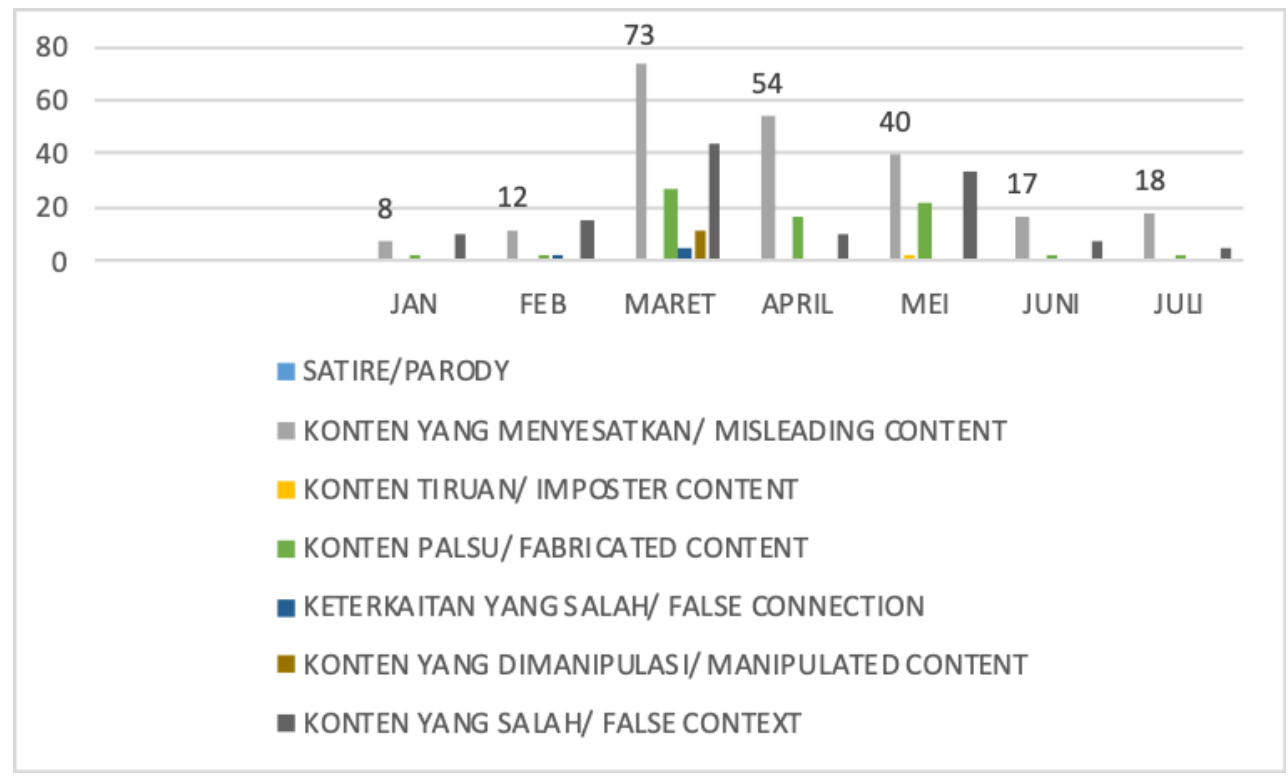

Figure 5. The Types of Misinformation and Disinformation of COVID-19 (Source: Primary Data, 2020)

According to First Draft, there are 7 types of misinformation and disinformation. The first is satire/ parody. It is a content which is not made for bad intention, but it can deceive the public. Then, the second is false connection which is a content whose title is different from the news content. The third is false context. It is a content presented with false context narration. Meanwhile, misleading content is a content which is changed to blemish. The fifth is imposter content which is a content taking advantage from public figure. The next is manipulated content. It is an existing content, but it is changed to deceive. The last one is fabricated content which is a fully fake content.

By UNESCO, satire/ parody is categorized into misinformation and disinformation because in the condition in which too much information is spreading out, then there are many parties probably do not comprehend if something they perceive is satire (Posetti et al., 2018). That is why, even though it belongs to the content that is not intentionally deceiving, satire still has the chance to make people misunderstand an information. Among 449 cases under study since January, satire/ parody cannot be found in the cases whose facts have been checked by Mafindo. 
The type of misinformation that is the most frequently produced and spread in society during the research period is misleading content. Misleading content is usually indicated by cutting photo and choosing quotation, statistics or data selectively (Posetti et al., 2018). The goal is to spread misleading information. The example of misleading content in this research is the case of Facebook account of Alexander Abu Taqi Mayestino who uploaded status with narration that compared the price of a monkey and that of Indonesian citizen. The issue was framed with the phenomenon of monkey shortage felt by a company in China so that it became the reason why China carried out vaccine clinical test in Indonesia. The post also included the news from Kompas.com entitled "Harga Mahal, Lab China Kekurangan Monyet untuk Uji Coba Vaksi Corona" (Expensive Price, China Lab Lacks Monkey to Do Corona Vaccine Test) and "Kabar Baik: Vaksin Covid-19 dari China Segera Uji Klinis di Indonesia Update 5 Vaksin Lainnya" (Good News: Covid-19 Vaccine from China Will Soon Have Clinical Test in Indonesia to Update the Other 5 Vaccines. The two news from Kompas were framed as if they were related to each other and used to support narration.

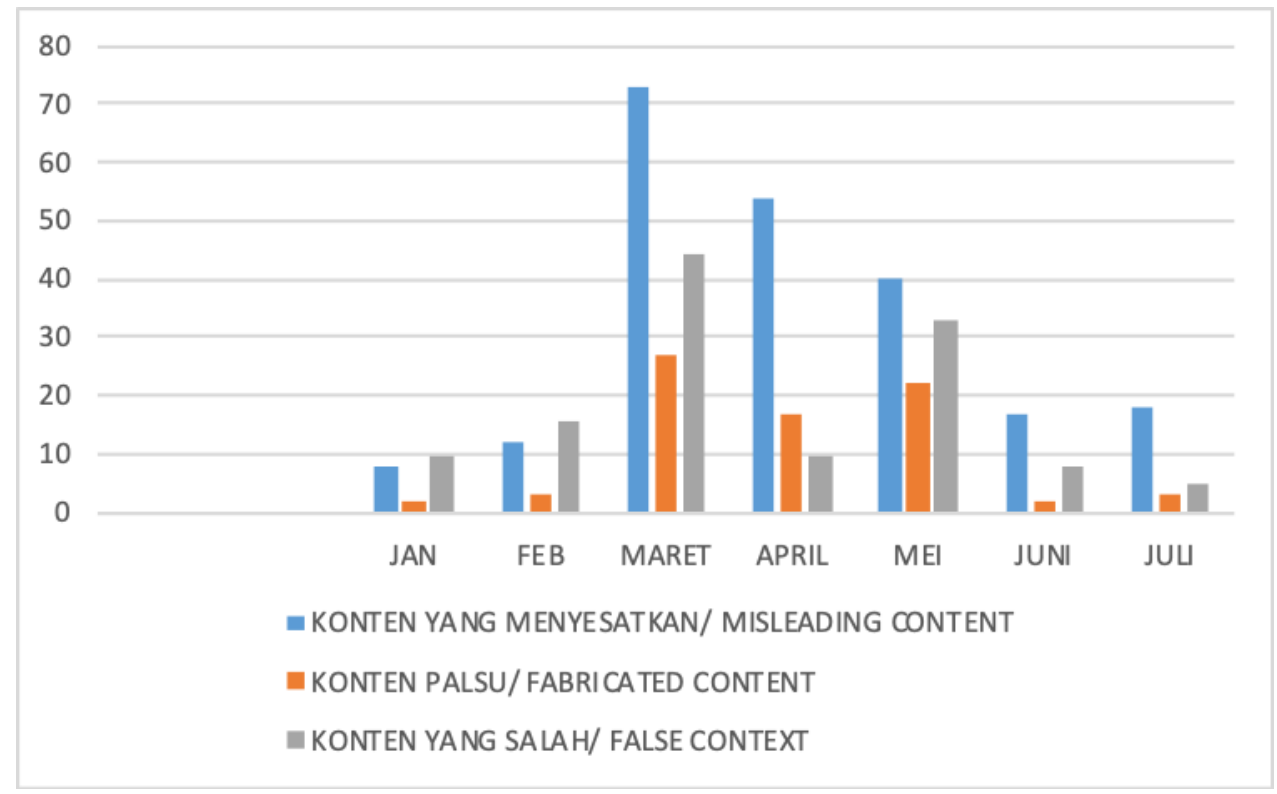

Figure 6. The Three Types of the Most Misinformation and Disinformation Produced (Source: Primary Data, 2020)

Beside misleading content, the types of misinformation and disinformation that are also frequently spreading are fabricated content and false context. Fabricated content can be analyzed through the elements of information disorder separately, namely agent, message, and interpreter (Posetti et al., 2018). For example, through the element of agent, the person who produced the fabricated content can be investigated. The message producer can be different from the distributor. The public also can see the motivation of the agent when producing and distributing it. It influences the analysis of message content and how far the damage scale caused by the message.

The example of fabricated content in this research is the spread of forwarded messages in WhatsApp stating that Domino's Pizza distributed free pizza voucher during COVID-19 pandemic era. The other example is forwarded messages through WhatsApp related to the emergence of new cluster of the virus spread in Golden Swalayan Kediri.

Meanwhile, false context is related to, for example, the spread of the post that has ever been uploaded before, and then it is distributed again in the different event context. For example, the post of Facebook account of Komar Komarudin showed the video of COVID-19 victim bodies in Mexico sea. The fact is that the video was skydiving action in order to break the world's record of paradiving by dropping 222 parachutists in Russia in 2018. 


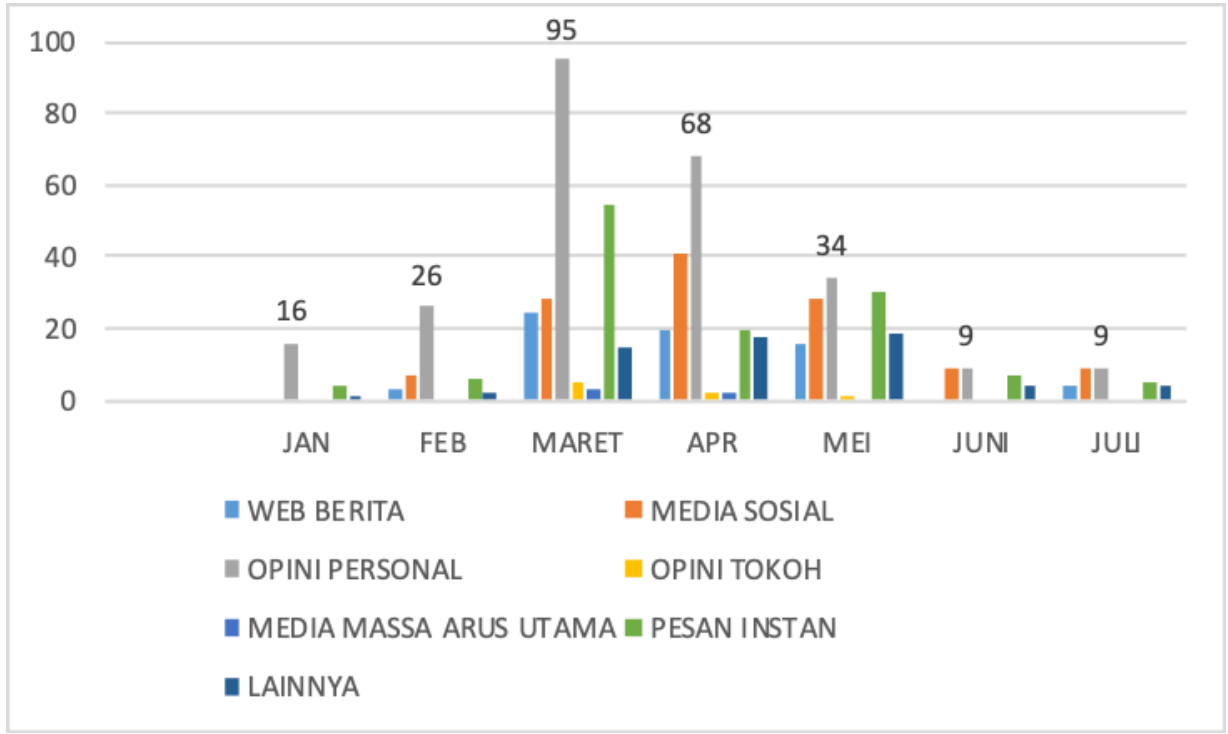

Figure 7. The Source of Misinformation and Disinformation (Source: Primary Data, 2020)

Figure 7 is really related to the finding shown in figure 3 and 4 . The massive use of social media and instant message make someone's personal opinion become easier to deliver. The freedom of a person to have communication media make anyone can talk about COVID-19 even though he is not competent. Beside personal opinion, the biggest source of misinformation and disinformation is instant message. Even though instant message is very likely produced by individual opinion, it is different in the context that the misinformation receiver does not know who intentionally produces and distributes it and neither does social media.

As a comparison, the percentage of public figure opinion as misinformation and disinformation source is very low because his opinion has more opportunity to be delivered through mass media. With such freedom, the public figure is not as free as common people or anonymous individual instead because mass media has verification principle which is stricter than social media and instant message.

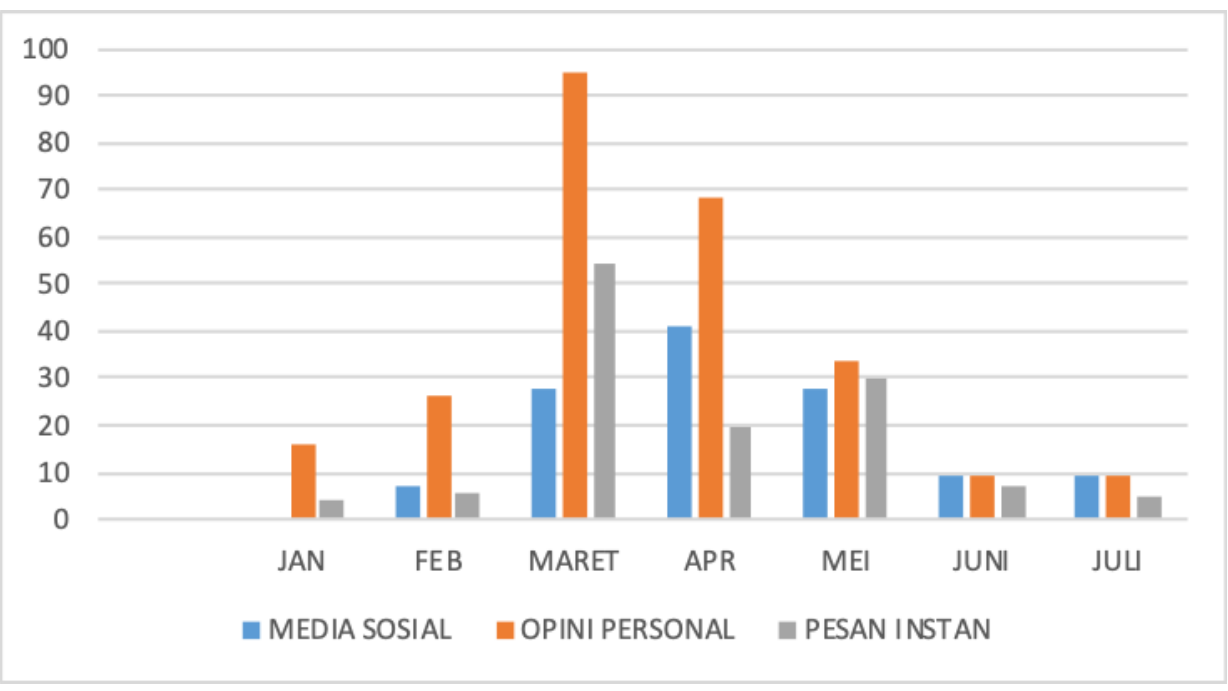

Figure 8. The Three Sources with the Most Misinformation and Disinformation Contained (Source: Primary Data, 2020) 
Figure 8 describes the possibility that both social media and instant message are produced by individual. With that kind of assumption, an individual has bigger role in producing and distributing misinformation content.

Generally, this research shows some tendencies. First, March, April, and May were the months with the highest intensity of misinformation and disinformation of COVID-19 during January - July period. Second, Facebook, Twitter and WhatsApp became the most frequently used media to spread misinformation about COVID-19 in Indonesia. Third, there were three types misinformation and disinformation about COVID-19 which were frequently produced and distributed the most, namely misleading content, fabricated content and false context. Fourth, personal opinion became the source with the most misinformation contained about COVID-19 during January- July 2020.

The massive spread of misinformation and disinformation of COVID-19 does not only occur in Indonesia, but also in many other places. WHO calls it infodemic. If seen from analysis frame of disinformation triangle, then disinformation is caused by 3 factors related in causal way (Victoria L. Rubin, 2019). In the context of this research, just like ferocious pathogen, misinformation of COVID19 gets massive because the lack of government intervention in giving information. It is closely related to the high demand of the public on information. When the issue faced is still very strange, but influential, then government intervention is needed. The intervention intended is the transparent and valid information. When the information intervention is low, then information-overloaded becomes a part of need and effect at once. Society tries to find information and the intensity of misinformation and disinformation is high. Just like selling and buying activity, this kind of condition is like meeting the demand and supply.

Figure 2 shows that the high intensity of disinformation occurred in March, April and May. Those times were indicated with various conditions that caused the panic of the society such as the appearance of patient 1 and patient 2 of COVID-19, the enforcement of the first PSBB followed by mobility restriction of the society and local area restriction.

In the model, Rubin offers three kinds of intervention to cope disinformation problem, namely automation, education and regulation. In her opinion, those 3 things are a comprehensive series of action to control, predict, and prevent fake information or even infodemic. Automation solution is related to the technology aspect that can detect fraud, clickbait, rumor and so on. She states that in the future, it has to be intensified so that the readers know that the information that they read has the potential to deceive. Thus, they are supported to do fact-check. Automation is considered as important because it can support human decision making (Victoria L. Rubin, 2019; Victorial L. Rubin, 2018).

If related to the research result, it can be seen that automation solution becomes very important in order to inhibit and decrease the opportunity of the people from getting exposed with misinformation and disinformation. It becomes easy to do regarding the characteristic of the message that is easy to identify and tends to be repetitive. For example, fake messages often use dramatization object, sensational content, and incomplete information element and narration logic. Regarding the tendency of the public to use multiplatform to access information (for example, using WhatsApp, Facebook, and Website at once), automation then has important role to massively restrict the spread of messages with misinformation disinformation.

Meanwhile, regulation refers to the restriction with rules because the practices in social media are related to business model such as virality considered more important than information quality. Rubin regards that the monopoly practice of platform provider also worsens the conducive situation of digital world (Victoria L. Rubin, 2019). In the context in Indonesia, the government has not been able to completely give a regulation that protect the society from social media provider aspect. Facebook as the media that has the highest number of active users also becomes the media used to spread misinformation and disinformation that almost has not been touched by regulation intervention of the government. The Laws No.11/ 2008 about Informasi dan Transaksi Elektronik (ITE) or Electronic Information and Transaction intended to protect the public from cyber crime becomes instead counterproductive with the freedom of expression and is not able to use to regulate social media platform.

Monopoly aspect stated by Rubin also becomes important especially when the research result showed that Facebook and WhatsApp were the media frequently used to spread misinformation. WhatsApp was acquired by Facebook in 2014.

The next is literacy that should be reinforced as a preventive step for the long term. It is getting urgent because the pattern found in the research result showed that misinformation and disinformation 
now has crossed country border. It means that the weakness of the regulation that often cannot access the condition outside Indonesia can be balanced with the capital of good literacy.

\section{CONCLUSION}

There are some tendencies of misinformation and disinformation of COVID-19 in Indonesia. The highest intensity of misinformation and disinformation of COVID-19 was in March, April, and May when the issue of COVID-19 was still new and confusing. In that kind of situation, the need of the society on information was very high, but the intervention of the government was still low to give solution to them. It then was used by some irresponsible people to spread misinformation and disinformation through the platform frequently used by Indonesian society, namely Facebook, Twitter, and WhatsApp. These platforms have similar characteristics such as easy to use including in sharing information across platform. The feature of the three media are also not difficult to operate so that they can reach all levels ofsociety.

The other tendency is misinformation content about corona plague widely spread is in the form of misleading content, fabricated content, and false context. They are easy to believe by society because of the characteristic of frequently modifying information from other credible sources so that they seem to be true. Personal opinion also becomes the source with the most misinformation of COVID19 contained during January-July 2020. It shows that the convenience to produce message supported with the more personal social media makes anyone can be source of news and can be trusted by the public.

\section{REFERENCES}

Ariani, Y. (2019). Riset Mandiri Tirto Siapa Penyebar Hoaks di Indonesia? Retrieved September 26, 2020, from Tirto website: https://tirto.id/siapa-penyebar-hoaks-di-indonesia-dCr2

Barua, Z., Barua, S., Aktar, S., Kabir, N., \& Li, M. (2020). Effects of misinformation on COVID-19 individual responses and recommendations for resilience of disastrous consequences of $\begin{array}{llllll}\text { misinformation. Progress in Disaster } & \text { Science, } & 8, & 100119 .\end{array}$ https://doi.org/10.1016/j.pdisas.2020.100119

Brennen, J. S., Simon, F. M., Howard, P. N., \& Nielsen, R. K. (2020). Types, Sources , and Claims of COVID-19 Misinformation. Oxford University Press, (April), 1-13.

Cinelli, M., Quattrociocchi, W., Galeazzi, A., Valensise, C. M., Brugnoli, E., Schmidt, A. L., ... Scala, A. (2020). The COVID-19 Social Media Infodemic. 1-18. Retrieved from http://arxiv.org/abs/2003.05004

Databoks. (2020). Ini Media Sosial Paling Populer Sepanjang April 2020. Retrieved October 3, 2020, from Katadata website: https://databoks.katadata.co.id/datapublish/2020/05/25/ini-mediasosial-paling-populer-sepanjang-april-2020

Djalante, R., Lassa, J., Setiamarga, D., Sudjatma, A., Indrawan, M., Haryanto, B., ... Warsilah, H. (2020). Review and analysis of current responses to COVID-19 in Indonesia: Period of January to March 2020. Progress in Disaster Science, 6, 100091. https://doi.org/10.1016/j.pdisas.2020.100091

Eriyanto. (2011). Analisi Isi Pengantar Metodologi untuk Penelitian Ilmu Komunikasi dan Ilmu-ilmu Sosial Lainnya. Jakarta: Kencana Prenada Media.

Hesthi Rahayu, W., \& Utari, P. (2018). Elaborasi Pesan Hoax Di Grup Facebook Info Wong Solo. Komunikator, 10(1), 24-33. https://doi.org/10.18196/jkm.101003

Jayani, Dwi Hadya. (2020). 10 Media Sosial yang Paling Sering Digunakan di Indonesia. Retrieved September 15, 2020, from wataboks https://databoks.katadata.co.id/datapublish/2020/02/26/10-media-sosial-yang-paling-seringdigunakan-di-indonesia

Jayani, Dwi Handya. (2020). 10 Media Sosial yang Paling Sering Digunakan di Indonesia. Retrieved October 3, 2020, from katadata website: https://databoks.katadata.co.id/datapublish/2020/02/26/10-media-sosial-yang-paling-seringdigunakan-di-indonesia

Karlova, N. A., \& Fisher, K. E. (2013). A social diffusion model of misinformation and 
disinformation for understanding human information behaviour. Information Research, 18(1). Retrieved from http://www.informationr.net/ir/18-1/paper573.html\#.X3gnYGgzY2y

Moudy, J., \& Syakurah, R. A. (2020). Pengetahuan terkait usaha pencegahan Coronavirus Disease (COVID-19) di Indonesia. Higeia Journal of Public Health Research and Development, 4(3), 333-346. https://doi.org/10.15294/higeia.v4i3.37844

Nadzir, I., Seftiani, S., \& Permana, Y. S. (2019). Hoax and Misinformation in Indonesia: Insights from a Nationwide Survey. Perspective, (92), 1-12. Retrieved from https://www.iseas.edu.sg/images/pdf/ISEAS_Perspective_2019_92.pdf

Nafi'an, M. I. (2020). Polda Metro Tangani 43 Kasus Hoax Terkait Wabah Corona, 4 Ditangkap. Retrieved September 26, 2020, from Detik.com website: https://news.detik.com/berita/d4959084/polda-metro-tangani-43-kasus-hoax-terkait-wabah-corona-4-ditangkap

Nasir, N. M., Baequni, B., \& Nurmansyah, M. I. (2020). Misinformation Related To Covid-19 in Indonesia. Jurnal Administrasi Kesehatan Indonesia, 8(2), 51. https://doi.org/10.20473/jaki.v8i2.2020.51-59

Nguyen, H., \& Nguyen, A. (2020). Covid-19 Misinformation and the Social (Media) Amplification of Risk: A Vietnamese Perspective. Media and Communication, 8(2), 444-447. https://doi.org/10.17645/mac.v8i2.3227

Oliveira, N. (2020). Dozens infected with coronavirus after church sprayed saltwater inside people's mouths using same nozzle. Retrieved September 26, 2020, from Daily News website: https://www.nydailynews.com/coronavirus/ny-coronavirus-south-korea-church-sprayed-saltwater-followers-20200317-ssyg42k5obephouqeg66yspxxy-story.html

Posetti, J., Ireton, C., Wardle, C., Derakhshan, H., Matthews, A., Abu-Fadil, M., ... Mantzarlis, A. (2018). JOURNALISM , 'FAKE NEWS' \& Handbook for Journalism Education and Training (C. Ireton \& J. Posetti, Eds.). Paris: United Nations Educational, Scientific and Cultural Organization.

Potkin, F., Damiana, J., \& Mano, A. (2019). Facebook's WhatsApp limits users to five text forwards to curb rumors. Retrieved October 3, 2020, from Reuters website: https://www.reuters.com/article/us-facebook-whatsapp/facebooks-whatsapp-limits-textforwards-to-five-recipients-to-curb-rumors-idUSKCN1PF0TP

Putri, V. M. (2020). Update: Ada 196 Hoax Virus Corona Ditemukan di Indonesia. Retrieved September 26, 2020, from Detik.com website: https://inet.detik.com/cyberlife/d4936108/update-ada-196-hoax-virus-corona-ditemukan-di-indonesia

Rahayu, R. N., \& Sensusiyati. (2020). Analisis Berita Hoax Covid - 19 Di Media Sosial Di Indonesia. Intelektiva: Jurnal Ekonomi, Sosial, \& Humaniora, 01(09), 60-73.

Roth, Y., \& Pickles, N. (2020). Bot atau bukan? Fakta tentang manipulasi platform di Twitter. Retrieved October 3, 2020, from Twitter website: https://blog.twitter.com/in_id/topics/company/2020/Bot-atau-bukan.html

Rubin, Victoria L. (2019). Disinformation and misinformation triangle: A conceptual model for "fake news" epidemic, causal factors and interventions. Journal of Documentation, 75(5), 10131034. https://doi.org/https://www.emerald.com/insight/content/doi/10.1108/JD-12-20180209/full/html

Rubin, Victorial L. (2018). Keynote Speech At The Information Without Borders Conference 2018. Retrieved October 3, 2020, from victoriarubin website: https://victoriarubin.fims.uwo.ca/2018/01/11/keynote-speech-information-without-bordersconference-2018/

Salsabila, I. (2018). Hoax Tewaskan Warga, India Ancam Hukum WhatsApp. Retrieved September 26, 2020, from detik website: https://inet.detik.com/cyberlife/d-4124856/hoax-tewaskanwarga-india-ancam-hukum-whatsapp

Sasmito, A. (2020). Kompilasi Post Periksa Fakta MAFINDO Berkaitan Dengan Virus Corona. Retrieved September 26, 2020, from Mafindo website: https://turnbackhoax.id/2020/02/06/kompilasi-post-periksa-fakta-mafindo-berkaitan-denganvirus-corona/

Syambudi, I. (2020). Lockdown Mandiri ala Jogja: Ditolak Pemerintah, Diinginkan Warga. Retrieved October 3, 2020, from Tirto website: https://tirto.id/lockdown-mandiri-ala-jogja-ditolakpemerintah-diinginkan-warga-eH3o

Wardle, C. (2017). Fake news. It's complicated. Retrieved April 14, 2020, from First Draft website: https://firstdraftnews.org/latest/fake-news-complicated/ 
Wardle, C. (2019). Understanding Information Disorder. In First Draft. https://doi.org/10.3726/978-30352-0191-8/4

White, M. D., \& Marsh, E. E. (2006). Content analysis: A flexible methodology. Library Trends, 55(1), 22-45. https://doi.org/10.1353/lib.2006.0053

WHO. (2020). Novel Coronavirus(2019-nCoV) Situation Report - 13. Retrieved from https://www.who.int/docs/default-source/coronaviruse/situation-reports/20200202-sitrep-13ncov-v3.pdf?sfvrsn=195f4010_6

Wibawa, S. W. (2020). Studi: 800 Orang Meninggal karena Hoaks Corona. Retrieved September 26, 2020, from Kompas.com website: https://www.kompas.com/sains/read/2020/08/13/180500023/studi-800-orang-meninggalkarena-hoaks-dan-teori-konspirasi-corona?page $=$ all

Widiatmojo, R. (2020). Literasi Visual Sebagai Penangkal Foto Hoax Covid-19. Sospol: Jurnal Sosial Politik, 6(1), 114-127.

Wu, L., Morstatter, F., Carley, K. M., \& Liu, H. (2019). Misinformation in social media: Definition, manipulation, and detection. ACM SIGKDD Explorations Newsletter, 21(2), 80-90. Retrieved from https://www.public.asu.edu/ huanliu/papers/Misinformation_LiangWu2019.pdf

Zarocostas, J. (2020). How to fight an infodemic. Lancet (London, England), 395(10225), 676. https://doi.org/10.1016/S0140-6736(20)30461-X 